\title{
Pengaruh Buah Sirsak Terhadap Faktor Risiko Kardiovaskular (Kolesterol Total, HDL, LDL, Trigliserida)
}

\author{
Haidar Alatas* \\ *Departemen Ilmu Penyakit Dalam Fakultas Kedokteran, Universitas Muhammadiyah Purwokerto
}

\author{
*) Correspondence Author \\ Haidar Alatas \\ Departemen Ilmu Penyakit Dalam Fakultas Kedokteran, Universitas Muhammadiyah Purwokerto \\ Email: haidar_papdi@yahoo.com
}

\begin{abstract}
Soursop fruit contains phenolic, tannins, flavonoids. Phenolic inhibit xanthine oxidase inhibitors which inhibit the production of uric acid, this will affect in decreasing cardiovascular risk. Tannins reducing triglyceride levels. Flavonoids reduce HMG-CoA reductase and total cholesterol. Several studies conducted on animal experiments and the results of soursop fruit reduce lipid profile. What is the effect of soursop fruit consumption on cardiovascular risk in healthy humans? This epidemiological research was conducted in Mlati, Sleman, Indonesia. There were 143 subjects that conform to the inclusion and exclusion criteria subsequently randomized to two groups. Group I was given $2 \times 100 \mathrm{~g}$ /day of soursop and group II was without soursop. A laboratory examination was conducted of total cholesterol, HDL, LDL, and triglyceride levels at weeks 0, 7, and 13 both in the soursop and non-soursop groups. Regular soursop consumption was evaluated every two weeks for three months. Data analysis was performed using an independent $t$ test, a nonparametric Mann-Whitney test, and a chi-square test. There was no significant difference in total cholesterol $(p=0.254$ and $p=0.932)$, HDL $(p=0.400$ and $p=0.960)$, LDL $(p=0.221$ and $p=0.710)$, triglycerides ( $p=0.423$ and $p=0.580$ ) between the soursop and non-soursop groups. The consumption of soursop fruit at $2 \times 100$ $\mathrm{g} /$ day has no significant effect on improvement in cardiovascular risk (total cholesterol, HDL, LDL, triglycerides) in healthy subjects, but in subjects with hypercholesterolemia and hypertriglyceridemia, the mean cholesterol and triglyceride levels decreased at week 7 and 13 compared to no soursop consumption.
\end{abstract}

Keyword: soursop, cardiovaskular, total cholesterol, HDL, LDL, triglyseride

\section{Abstrak}

Buah sirsak mengandung senyawa fenolik yang bersifat xanthine oksidase inhibitor yang akan menghambat produksi asam urat, penurunan kadar asam urat berpengaruh dengan penurunan risiko kardiovaskular. Buah sirsak mengandung tanin yang berperan dalam penurunan kadar trigliserida. Buah sirsak juga mengandung flavonoid yang dapat menurunkan HMG-CoA reduktase, sehingga akan menurunkan kolesterol total. Beberapa penelitian telah dilakukan pada binatang percobaan dan hasilnya buah sirsak dapat menurunkan faktor risiko kardiovaskular (Kolesterol Total, HDL, LDL dan Trigliserida). Bagaimana pengaruh buah sirsak terhadap faktor risiko kardiovaskular pada manusia sehat? Penelitian epidemiologi di wilayah Mlati, Sleman, Indonesia. Didapatkan 143 subyek yang memenuhi kriteria inklusi dan eksklusi. Selanjutnya diacak menjadi 2 kelompok, kelompok I diberikan perlakuan 2x100 g/hari buah sirsak dan kelompok II tanpa perlakuan. Dilakukan pemeriksaan laboratorium Kolesterol total, LDL, HDL, Trigliserida pada minggu 0,7,13 baik pada kelompok sirsak dan non-sirsak. Evaluasi kepatuhan konsumsi sirsak setiap 2 minggu selama 3 bulan. Analisis data menggunakan Independent $t$ test, Nonparametrik Mann-Whitney test, Chi-Square test. Tidak ada perbedaan bermakna pada kadar Kolesterol total $(p=0.254$ dan $p=0.932)$, HDL $(p=0.400$ dan $p=0.960)$, LDL $(p=0.221$ dan $p=0.710)$, Trigliserida $(p=0.423$ dan $p=0.580$ ) antara kelompok sirsak dan non-sirsak. Konsumsi buah sirsak $2 \times 100 \mathrm{~g} /$ hari tidak berbeda bermakna dalam memperbaiki risiko kardiovaskular (Kolesterol total, HDL, LDL, Trigliserida) pada subyek normal, tetapi pada subyek dengan hiperkolesterol dan hipertrigliserida rerata kadar kolesterol dan trigliserida turun pada minggu 7 dan 13 dibanding tanpa konsumsi sirsak.

Kata kunci: buah sirsak, kardiovaskular, kolesterol total, HDL, LDL, trigliserida 


\section{PENDAHULUAN}

Tanaman sirsak sudah diketahui oleh masyarakat. Tanaman sirsak banyak dihasilkan di Indonesia, karena tanah Indonesia sangat cocok untuk pertumbuhannya. Tanaman sirsak dapat tumbuh di sembarang tempat tapi biasanya paling banyak tumbuh di daerah cukup berair, dari dataran rendah sampai ketinggian 1,200 mdpL. Sirsak atau sirsat juga dikenal dengan sebutan Durian Belanda sebenarnya merupakan tumbuhan yang berasal dari Karibia, Amerika Tengah dan Amerika Selatan. Buah ini masuk ke Indonesia pada waktu pemerintahan kolonial Belanda pada abad $19^{1-3}$.

Buah sirsak termasuk buah semu dengan daging buah yang lunak atau lembek, berwarna putih, berserat, berbiji pipih, berwarna hitam. Daging buah sirsak rasanya manis atau manis asam, segar beraroma khas. Apabila sudah matang, warna kulit buahnya agak terang, hijau kekuningan dan mengilap. Bagian ujung buah sirsak agak membulat dengan diameter sekitar 5 $\mathrm{cm}$. Diameter bagian tengah sekitar $7 \mathrm{~cm}$ dan panjang buahnya sekitar $17 \mathrm{~cm}$. Buah ini akan siap panen setelah 3 bulan dari terjadinya pembuahan ${ }^{4}$.

Secara fitokimia sirsak mengandung alkaloid, acetogenin, komponen fenolik dan komponen lain. Terdapat 37 komponen fenolik yang dilaporkan pada sirsak. Komponen fenolik yang penting adalah quercetin, gallic acid, flavonoids, lipophilic antioksidan. Komponen lain pada sirsak yaitu vitamin, karotenoids, amides, siklopeptid dan megastimanes. Ditemukan dua ratus dua belas senyawa bioaktif yang telah dilaporkan pada sirsak (Annona muricata). Komponen utamanya adalah acetogenins diikuti oleh alkaloid, fenol dan senyawa lainnya. Daun dan biji sirsak adalah paling sering diteliti, mungkin karena ini paling banyak digunakan secara tradisional. Mayoritas fitokimia telah diidentifikasi dari ekstrak organik, namun baru-baru ini fokus pada ekstrak air. Beberapa senyawa yang lain seperti karbohidrat dan minyak essensial juga telah dilaporkan ${ }^{5}$.

Tia 2014 dalam penelitiannya tentang pengaruh berbagai dosis jus buah sirsak (Annona muricata L.) terhadap penurunan kadar kolesterol low density lipoprotein (LDL) serum tikus putih (rattus norvegicus) dislipidemia menyimpulkan bahwa ada pengaruh pemberian berbagai dosis jus buah sirsak terhadap penurunan kadar kolesterol LDL, semakin besar dosis semakin besar penurunan LDL ${ }^{6}$. Tugiyanti 2016 dalam penelitiannya tentang pengaruh tepung daun sirsak (Annona muricata L.) terhadap karakteristik lemak darah dan daging itik tegal jantan menyimpulkan bahwa sirsak tidak dapat menurunkan kadar trigliserida, kolesterol, dan LDL darah serta kadar trigliserida dan kolesterol daging itik ${ }^{7}$. Penelitian de la Cruz 2016 menyimpulkan bahwa buah sirsak yang dikeringkan secara signifikan menurunkan kadar kolesterol, trigliserida, LDL kolesterol pada tikus hiperlipidemia. Dosis buah sirsak yang digunakan 500, 
1000, 2000 mg/kg BB. Makin tinggi dosis maka makin besar penuruan kadar kolesterol, trigliserida, dan makin rendah kadar LDL ${ }^{8}$. Sasso et al., 2019 dalam penelitiannya tentang ekstrak daun sirsak untuk mencegah peningkatan lemak pada tikus menyimpulkan bahwa ekstrak daun sirsak untuk profil kolesterol secara signifikan menurunkan LDL, VLDL, Trigliserida dan meningkatkan HDL kolesterol. Tetapi ekstrak daun sirsak pada tikus untuk kolesterol total tidak ada perubahan signifikan dibanding kelompok kontrol ${ }^{9}$.

Penelitian ini bertujuan mengkaji secara ilmiah pada manusia sehat dengan metode RCT tentang pengaruh buah sirsak terhadap faktor risiko kardiovaskular (Kolesterol Total, HDL, LDL dan Trigliserida).

\section{METODE}

Penelitian ini merupakan bagian dari penelitian epidemiologi tentang pengaruh konsumsi buah sirsak pada subyek sehat. Sebelum penelitian, desain penelitian telah disetujui oleh Komite Etika Penelitian Medis dan Kesehatan (MHREC) dari Fakultas Kedokteran, Universitas Gadjah Mada - Rumah Sakit Umum Dr. Sardjito Yogyakarta. Setelah diberi informasi tentang penelitian ini, subjek diminta untuk mengisi dan menandatangani formulir kesediaan untuk berpartisipasi (informed consent).
Data diambil dari Mlati Study, berusia 30-59 tahun, laki-laki dan perempuan dan sehat. Lokasi penelitian di wilayah Mlati, Sleman, Yogyakarta, Indonesia. Sampel acak dengan menggunakan simple random sampling dengan perangkat lunak SPSS 22. Didapatkan 143 subyek yang memenuhi kriteria inklusi dan eksklusi. Dari 143 subyek diacak kembali menjadi dua kelompok, kelompok I diberi buah sirsak 2x100 g/hari dan kelompok II tanpa sirsak. Pemeriksaan laboratorium kolesterol total, HDL, LDL dan trigliserida dilakukan pada minggu ke 0,7 , dan 13 pada kelompok sirsak dan non-sirsak. Kesesuaian dengan konsumsi sirsak dievaluasi setiap 2 minggu selama 3 bulan.

\section{DISKUSI}

Sirsak mengandung senyawa fenolik yang bersifat xanthine oksidase inhibitor yang akan menghambat produksi asam urat ${ }^{10}$. Penurunan kadar asam urat berpengaruh dengan penurunan risiko kardiovaskular. Daun sirsak mengandung tanin, flavonoid ${ }^{9}$, buah sirsak juga mengandung tanin ${ }^{11}$ yang berperan dalam penurunan ureum, kreatinin ${ }^{12}$ dan trigliserida ${ }^{13}$ yang berakibat meningkatkan laju filtrasi glomerulus. Peningkatan laju filtrasi glomerulus akan mengurangi risiko kardiovaskular. Buah sirsak juga mengandung flavonoid ${ }^{5}$ yang dapat menurunkan HMG-CoA reduktase ${ }^{7,13}$. Hal ini akan menyebabkan penurunan kadar kolesterol. Penurunan kadar 
kolesterol akan mengakibatkan penurunan risiko kardiovaskular (Gambar 1.).

Hasil penelitian Pengaruh Buah Sirsak Terhadap Faktor Risiko Kardiovaskular (Kolesterol Total, HDL, LDL dan Trigliserida) ternyata tidak ada perbedaan signifikan pada Kolesterol total minggu ke-7 dan ke-13 antara kelompok sirsak dan non sirsak $(p=0.254)$ dan $(p=0.932)$. Tidak ada perbedaan signifikan pada HDL minggu ke-7 dan ke-13 antara kelompok sirsak dan non sirsak $(p=0.400)$ dan $(p=0.960)$. Tidak ada perbedaan signifikan pada LDL minggu ke-7 dan ke-13 antara kelompok sirsak dan non sirsak $(p=0.221)$ dan $(p=$ 0.710). Tidak ada perbedaan signifikan pada Trigliserida minggu ke-7 dan ke-13 antara kelompok sirsak dan non sirsak $(p=0.423)$ dan $(p=0.580)$ (Tabel 1.)

Hasil penelitian yang dilakukan oleh Tia et al. 2014 tentang Pengaruh berbagai dosis jus buah sirsak (Annona muricata L.) terhadap penurunan kadar kolesterol low density lipoprotein (LDL) serum tikus putih (rattus norvegicus) dislipidemia, didapatkan persentase penurunan kadar kolesterol LDL serum tikus putih dari berbagai dosis jus buah sirsak, yaitu 0,9 $\mathrm{g} / 200 \mathrm{~g}$ BB sebesar 46,19\%, dosis 1,8 g/200 g BB sebesar 52,30\% dan dosis 2,7 g/200 g BB sebesar 61,62\%. Disimpulkan bahwa ada pengaruh pemberian berbagai dosis jus buah sirsak terhadap penurunan kadar kolesterol LDL pada serum tikus putih dislipidemia. Semakin besar dosis jus buah sirsak yang diberikan semakin besar penurunan kadar kolesterol LDL pada serum tikus putih dislipidemia ${ }^{6}$. Tugiyanti 2016 dalam penelitiannya tentang Pengaruh tepung daun sirsak (Annona muricata L.) terhadap karakteristik lemak darah dan daging itik tegal jantan menyimpulkan bahwa sirsak tidak dapat menurunkan kadar trigliserida, kolesterol, dan LDL darah serta kadar trigliserida dan kolesterol daging itik ${ }^{7}$. Penelitian de la Cruz 2016 menyimpulkan bahwa buah sirsak yang dikeringkan secara signifikan menurunkan kadar kolesterol, trigliserida, LDL kolesterol pada tikus hiperlipidemia. Dosis buah sirsak yang digunakan 500, 1000, $2000 \mathrm{mg} / \mathrm{kg}$ BB. Makin tinggi dosis maka makin besar penurunan kadar kolesterol, trigliserida, dan makin rendah kadar $\mathrm{LDL}^{8}$ (Tabel 2.).

Sasso et al., 2019 dalam penelitiannya tentang ekstrak daun sirsak untuk mencegah peningkatan lemak pada tikus menyimpulkan bahwa ekstrak daun sirsak untuk profil kolesterol secara signifikan menurunkan LDL, VLDL, Trigliserida dan meningkatkan HDL kolesterol. Tetapi ekstrak daun sirsak pada tikus untuk kolesterol total tidak ada perubahan signifikan dibanding kelompok kontrol ${ }^{9}$.

Penelitian Tia (2014) pada tikus dislipidemia jus buah sirsak dapat menurunkan LDL. Penelitian de la Cruz (2016) pada tikus hiperlipidemia buah sirsak dapat menurunkan kolesterol, trigliserida, LDL. Mengapa hasil penelitian ini (Haidar) tidak berpengaruh signifikan terhadap penurunan kolesterol 
total, LDL, trigliserida dan peningkatan HDL pada minggu ke-7 dan ke-13 kelompok sirsak dan non sirsak? Peneliti menduga karena subyek penelitian adalah subyek sehat bukan pada subyek dengan gangguan kardiovaskular (dislipidemia) seperti pada penelitian lain dan yang diteliti adalah manusia bukan binatang percobaan. Oleh karena itu, peneliti mencoba menganalisis kembali data dari subyek yang awalnya dislipidemia (hiperkolesterol, LDL tinggi, HDL rendah dan hipertrigliserida).

Pada subyek yang awalnya hiperkolesterol (> $200 \mathrm{mg} / \mathrm{dL}$ ) didapatkan 22 subyek pada minggu 0 , menjadi 17 pada minggu 7 dan minggu 13. Nilai rerata subyek hiperkolesterol konsumsi sirsak, pada minggu ke-7 mengalami penurunan rerata kolesterol dari 221 menjadi $213 \mathrm{mg} / \mathrm{dL}$. Sedangkan pada minggu ke-13 nilai rerata kolesterol turun dari 221 menjadi 197 $\mathrm{mg} / \mathrm{dL}$ bila dibanding dengan minggu awal. Dari minggu ke-7 hingga minggu ke-13 nilai rerata kolesterol turun dari 213 menjadi $197 \mathrm{mg} / \mathrm{dL}$. Dibanding nilai rerata subyek hiperkolesterol tanpa konsumsi sirsak, pada minggu ke-7 tidak mengalami penurunan rerata kolesterol dari 223 menjadi 223 mg/dL. Sedangkan pada minggu ke-13 nilai rerata kolesterol dari 223 menjadi $220 \mathrm{mg} / \mathrm{dL}$ bila dibanding dengan minggu awal. Kelompok yang tanpa konsumsi sirsak pada subyek dengan hiperkolesterol selama 13 minggu hampir tidak ada perubahan (Tabel 3.).
Pada subyek yang awalnya LDL tinggi (> 100 $\mathrm{mg} / \mathrm{dL}$ ) didapatkan 81 subyek pada minggu 0 menjadi 63 minggu 7 dan menjadi 61 minggu 13. Nilai rerata subyek LDL tinggi konsumsi sirsak, pada minggu ke-7 dari 126 menjadi $135 \mathrm{mg} / \mathrm{dL}$ dan minggu 13 dari 126 menjadi $130 \mathrm{mg} / \mathrm{dL}$. Dibanding nilai rerata subyek LDL tinggi tanpa konsumsi sirsak, pada minggu ke-7 rerata LDL dari 131 menjadi 137 mg/dL. Sedangkan pada minggu ke-13 nilai rerata LDL dari 131 menjadi $134 \mathrm{mg} / \mathrm{dL}$ bila dibanding dengan minggu awal (Tabel 4.).

Pada subyek yang awalnya HDL rendah $(<40$ $\mathrm{mg} / \mathrm{dL}$ ) didapatkan 60 subyek pada minggu 0 , menjadi 49 minggu 7 dan menjadi 46 minggu 13. Nilai rerata subyek HDL rendah konsumsi sirsak, pada minggu ke7 dan minggu 13 mengalami peningkatan dari 32 menjadi 40 dan $41 \mathrm{mg} / \mathrm{dL}$. Dibanding nilai rerata subyek HDL rendah tanpa konsumsi sirsak, pada minggu ke-7 dan 13 mengalami peningkatan dari 32 menjadi 40 dan $42 \mathrm{mg} / \mathrm{dL}$ (Tabel 5.).

Pada subyek yang awalnya hipertrigliserida (> $150 \mathrm{mg} / \mathrm{dL}$ ) didapatkan 35 subyek pada minggu 0 , menjadi 29 minggu 7 dan menjadi 28 minggu 13. Nilai rerata subyek hipertrigliserida konsumsi sirsak, pada minggu ke-7 dan 13 dari 205 menjadi 183 dan 188 mg/dL. Dibanding nilai rerata subyek hipertrigliserida tanpa konsumsi sirsak, pada minggu ke-7 dan 13 dari 233 menjadi 339 dan 324 mg/dL (Tabel 6.). 


\section{SIMPULAN}

Pengaruh Buah Sirsak Terhadap Faktor Risiko Kardiovaskular (Kolesterol Total, HDL, LDL dan Trigliserida) adalah pada subyek manusia sehat tidak berbeda bermakna dalam menurunkan kolesterol total, LDL, trigliserida dan tidak berbeda bermakna dalam menaikkan HDL pada minggu ke-7 dan 13 kelompok sirsak dan non-sirsak. Tetapi pada subyek dengan hiperkolesterol dan hipertrigliserida yang konsumsi buah sirsak rerata kadar kolesterol dan trigliserida turun pada minggu 7 dan 13 dibanding tanpa konsumsi sirsak.

\section{DAFTAR PUSTAKA}

1. Cheong KW, Tan CP, Mirhosseini H, Chin ST, Che Man YB, Hamid NSA, et al. Optimization of equilibrium headspace analysis of volatile flavor compounds of malaysian soursop (Annona muricata): Comprehensive two-dimensional gas chromatography time-of-flight mass spectrometry (GC $\times$ GC-TOFMS). Food Chemistry. 2011;125(4):1481-9. Available from: http://www.sciencedirect.com/science/article/pii/S 0308814610013245

2. Sobrinho RB, Bandeira CT, Mesquita ALM. Occurrence and damage of soursop pests in northeast Brazil. Crop Protection. 1999;18(8):539-41. Available from: http://www.sciencedirect.com/science/article/pii/S 0261219499000514

3. Kim G-S, Zeng L, Alali F, Rogers LL, Wu F-E, Sastrodihardjo $\mathrm{S}$, et al. Muricoreacin and murihexocin $\mathrm{C}$, mono-tetrahydrofuran acetogenins, from the leaves of annona muricata in honour of professor G. H. Neil Towers 75th birthday. Phytochemistry. 1998;49(2):565-71. Available from: http://www.sciencedirect.com/science/article/pii/S 0031942298001721
4. Adeyemi DO, Komolafe OA, Adewole SO, Obuotor EM, Adenowo TK. Effects Of Annona Muricata (Linn) On The Morphology Of Pancreatic Islet Cells Of Experimentally-Induced Diabetic Wistar Rats. The Internet Journal of Alternative Medicine. 2007;5(2):8. Available from:

https://www.semanticscholar.org/paper/EffectsOf-Annona-Muricata-(Linn)-On-The-

Morphology-Adeyemi-

Komolafe/1d4382cadf6f832a02c8276d935ba8a55 086c0f3

5. Coria-Téllez AV, Montalvo-Gónzalez E, Yahia EM, Obledo-Vázquez EN. Annona muricata: A comprehensive review on its traditional medicinal uses, phytochemicals, pharmacological activities, mechanisms of action and toxicity. Arab J Chem. 2016; Available from: http://www.sciencedirect.com/science/article/pii/S 1878535216000058

6. Tia HD, Sistiyono S, Hendarta NY. Pengaruh Berbagai Dosis Jus Buah Sirsak (Annona muricata L.) Terhadap Penurunan Kadar Kolesterol Low Density Lipoprotein (LDL) Serum Tikus Putih (Rattus norvegicus) Dislipidemia. Jurnal Teknologi Laboratorium. 2014;3(2):84-90. Available from: https://www.teknolabjournal.com/index.php/Jtl/ar ticle/view/65

7. Tugiyanti E, Heriyanto S, Syamsi AN. Pengaruh Tepung Daun Sirsak (Announa Muricata L) terhadap Karakteristik Lemak Darah dan Daging Itik Tegal Jantan. Buletin Peternakan. 2016;40(3):211. Available from: https://journal.ugm.ac.id/buletinpeternakan/article /view/11243

8. de la Cruz AMA, Catabay AP. Hypolipidemic Effect of the Lyophilized Fruit Pulp of Guyabano, Annona Muricata Linn. (Fam. Annonaceae) in Atherogenic Diet-Induced Hyperlipidemia in Albino Rats. JAASP. 2016;1:351-9. Available from:

http://www.aaspjournal.org/abstractinfo.php?id=7 4

9. Sasso S, Sampaio e Souza PC, Santana LF, Cardoso CAL, Alves FM, Portugal LC, et al. Use of an Extract of Annona muricata Linn to Prevent High-Fat Diet Induced Metabolic Disorders in C57BL/6 Mice. Nutrients. 2019;11(7). Available from: 
https://www.ncbi.nlm.nih.gov/pmc/articles/PMC6 682994/

10. Ewadh MJ, Smaism MF, Jawad AM, Mkhlof S, Aljubouri OM, Ewadh MM. Using Soursop Extracts for Natural Gout Treatment. J Biosci Bioeng. 2015;3(5):37. Available from: http://www.sciencepublishinggroup.com/journal/p aperinfo?journalid $=217 \&$ doi $=10.11648 /$ j.bio .2015 0305.12

11. Onyechi AU, Ibeanu VN, Eme PE, Kelechi M. Nutrient, Phytochemical Composition and Consumption Pattern of Soursop (Annona muricata) Pulp and Drink among Workers in University of Nigeria, Nsukka Community. Pakistan Journal of Nutrition. 2015;14(12):86670. Available from: https://scialert.net/abstract/?doi=pjn.2015.866.870

12. Yokozawa T, Chung HY, He LQ, Oura H. Effectiveness of Green Tea Tannin on Rats with Chronic Renal Failure. Biosci Biotechnol Biochem. 1996;60(6):1000-5. Available from: https://www.jstage.jst.go.jp/article/bbb1992/60/6/ 60_6_1000/_article

13. Wurdianing I, Nugraheni SA, Rahfiludin Z. Efek Ekstrak Daun Sirsak (Annona Muricata Linn) Terhadap Profil Lipid Tikus Putih Jantan (Rattus Norvegicus). JGI. 2014;3(1):7-12. Available from:

https://www.neliti.com/publications/79681/efekekstrak-daun-sirsak-annona-muricata-linnterhadap-profil-lipid-tikus-putih 


\section{Pengakuan}

Tidak ada konflik interest dalam penelitian ini. Terima kasih kepada tim Mlati Studi.

\section{Tabel}

Tabel 1. Hasil Penelitian Pengaruh Buah Sirsak Terhadap Faktor Risiko Kardiovaskular (Kolesterol Total, HDL, LDL dan Trigliserida)

\begin{tabular}{|c|c|c|c|c|c|c|c|c|c|}
\hline \multirow{3}{*}{ Var } & \multicolumn{3}{|c|}{ Minggu 0} & \multicolumn{3}{|c|}{ Minggu 7} & \multicolumn{3}{|c|}{ Minggu 13} \\
\hline & $\begin{array}{l}\text { Sirsak } \\
n=71\end{array}$ & $\begin{array}{c}\text { Non-sirsak } \\
n=72\end{array}$ & $p$ & $\begin{array}{l}\text { Sirsak } \\
n=56\end{array}$ & $\begin{array}{l}\text { Non-sirsak } \\
\qquad n=60\end{array}$ & $p$ & $\begin{array}{l}\text { Sirsak } \\
n=54\end{array}$ & $\begin{array}{c}\text { Non-sirsak } \\
n=58\end{array}$ & $p$ \\
\hline & Mean (SD) & Mean (SD) & & Mean (SD) & Mean (SD) & & Mean (SD) & Mean (SD) & \\
\hline $\begin{array}{l}\text { Kol Tot } \\
\text { (mg/dL) }\end{array}$ & $\begin{array}{l}164.76 \\
(34.20)\end{array}$ & $\begin{array}{l}167.81 \\
(34.33)\end{array}$ & $0.596^{*}$ & $\begin{array}{l}191.59 \\
(27.86)\end{array}$ & $\begin{array}{l}187.77 \\
(31.91)\end{array}$ & $0.254^{*}$ & $\begin{array}{l}182.81 \\
(21.84)\end{array}$ & $\begin{array}{l}185.86 \\
(28.26)\end{array}$ & $0.932^{*}$ \\
\hline $\begin{array}{c}\text { LDL } \\
(\mathbf{m g} / \mathbf{d L})\end{array}$ & $\begin{array}{l}108.51 \\
(26.74)\end{array}$ & $\begin{array}{l}109.04 \\
(30.78)\end{array}$ & $0.912 *$ & $\begin{array}{l}127.57 \\
(21.72)\end{array}$ & $\begin{array}{l}121.67 \\
(28.57)\end{array}$ & $0.221 *$ & $\begin{array}{l}124.33 \\
(18.92)\end{array}$ & $\begin{array}{l}121.95 \\
(27.21)\end{array}$ & $0.710^{*}$ \\
\hline $\begin{array}{c}\text { HDL } \\
(\mathrm{mg} / \mathrm{dL})\end{array}$ & $41.54(10.11)$ & $\begin{array}{c}42.85 \\
(10.54)\end{array}$ & $0.449^{*}$ & $44.18(9.28)$ & $44.30(11.85)$ & $0.400 *$ & $\begin{array}{c}45.30 \\
(10.03)\end{array}$ & $47.12(13.00)$ & $0.960^{*}$ \\
\hline $\begin{array}{c}\text { Trigli } \\
\text { (mg/dL) }\end{array}$ & $\begin{array}{l}118.54 \\
(69.25)\end{array}$ & $\begin{array}{l}124.47 \\
(74.55)\end{array}$ & $0.634 * *$ & $\begin{array}{l}147.54 \\
(86.42)\end{array}$ & $\begin{array}{c}168.32 \\
(198.05)\end{array}$ & $0.423 * *$ & $\begin{array}{l}138.81 \\
(60.82)\end{array}$ & $\begin{array}{c}164.66 \\
(168.12)\end{array}$ & $0.580 * *$ \\
\hline
\end{tabular}

Tabel 2. Perbandingan Hasil Penelitian Pengaruh Buah Sirsak Terhadap Faktor Risiko Kardiovaskular (Kolesterol Total, HDL, LDL dan Trigliserida) Dengan Peneliti Lain

\section{$\begin{array}{llll}\text { Haidar, 2020 } & \text { Tia, } 2014 & \text { Tugiyanti, } 2016 & \text { de la Cruz, } 2016\end{array}$}

\begin{tabular}{lllll}
\hline Material & Jus buah sirsak & Jus buah sirsak & Tepung daun sirsak & Buah sirsak kering \\
\hline Subyek & Manusia sehat & Tikus dislipidemia & Itik sehat & Tikus hiperlipidemia \\
\hline Pemberian & Oral & Oral & Oral & Oral \\
\hline Dosis & $2 \times 100 \mathrm{~g} / \mathrm{hari}$ & $0.9 \mathrm{~g} / 200 \mathrm{~g} \mathrm{BB}$ & Pakan ternak $+5 \% ;$ & $500 \mathrm{mg} / \mathrm{kgBB}$ \\
& & $1.8 \mathrm{~g} / 200 \mathrm{~g} \mathrm{BB}$ & $10 \% ; 15 \%$ tepung & $1,000 \mathrm{mg} / \mathrm{kgBB}$ \\
\hline Metode & Kohort selama $3 \mathrm{bulan}$, & Control group design & Rancangan acak & Rancang acak lengkap \\
& RCT & & lengkap $5 \mathrm{ming} g \mathrm{mu}$ & selama $30 \mathrm{hari}$
\end{tabular}


Hasil

Tidak berpengaruh

signifikan terhadap

penurunan kolesterol,

LDL, trigliserida dan

peningkatan HDL pada

minggu ke-7 dan ke-13.

Ada pengaruh
pemberian berbagai
dosis jus buah sirsak
terhadap penurunan
kadar kolesterol LDL,
Semakin besar dosis
semakin besar
penurunan LDL.

Tidak dapat

menurunkan kadar

trigliserida,

kolesterol, dan LDL

darah serta kadar

trigliserida dan

kolesterol daging itik.
Secara signifikan

menurunkan kadar

kolesterol, trigliserida,

LDL. Makin tinggi dosis

maka makin besar penurunannya.

Tabel 3. Rerata Subyek Hiperkolesterol Pada Minggu 0, 7, 13 Kelompok Sirsak dan Non Sirsak

\begin{tabular}{cccccc}
\hline & $\begin{array}{c}\text { Minggu 0 } \\
(\mathbf{n = 2 2})\end{array}$ & \multicolumn{2}{c}{$\begin{array}{c}\text { Minggu 7 } \\
(\mathbf{n}=17)\end{array}$} & \multicolumn{2}{c}{ Minggu 13 } \\
$(\mathbf{n}=\mathbf{1 7})$
\end{tabular}

Tabel 4. Rerata Subyek LDL Tinggi Pada Minggu 0, 7, 13 Kelompok Sirsak dan Non Sirsak

\begin{tabular}{|c|c|c|c|c|c|}
\hline \multicolumn{2}{|c|}{$\begin{array}{l}\text { Minggu } 0 \\
(\mathbf{n}=\mathbf{8 1})\end{array}$} & \multicolumn{2}{|c|}{$\begin{array}{c}\text { Minggu } 7 \\
(n=63)\end{array}$} & \multicolumn{2}{|c|}{$\begin{array}{l}\text { Minggu } 13 \\
\quad(n=61)\end{array}$} \\
\hline $\begin{array}{l}\text { Sirsak } \\
(n=42)\end{array}$ & $\begin{array}{c}\text { Non Sirsak } \\
(\mathbf{n}=39)\end{array}$ & $\begin{array}{l}\text { Sirsak } \\
(n=33)\end{array}$ & $\begin{array}{c}\text { Non Sirsak } \\
(\mathbf{n}=\mathbf{3 0})\end{array}$ & $\begin{array}{l}\text { Sirsak } \\
(n=32)\end{array}$ & $\begin{array}{c}\text { Non Sirsak } \\
\qquad(\mathbf{n}=\mathbf{2 9})\end{array}$ \\
\hline 126.86 & 131.69 & 135.73 & 137.07 & 130.53 & 134.24 \\
\hline \pm 16.75 & \pm 21.53 & \pm 20.44 & \pm 24.38 & \pm 18.20 & \pm 26.61 \\
\hline
\end{tabular}

Tabel 5. Rerata Subyek HDL Rendah Pada Minggu 0, 7, 13 Kelompok Sirsak dan Non Sirsak

\begin{tabular}{|c|c|c|c|c|c|}
\hline \multicolumn{2}{|c|}{$\begin{array}{l}\text { Minggu } 0 \\
\qquad(\mathbf{n}=60)\end{array}$} & \multicolumn{2}{|c|}{$\begin{array}{c}\text { Minggu } 7 \\
(n=49)\end{array}$} & \multicolumn{2}{|c|}{$\begin{array}{c}\text { Minggu } 13 \\
(n=46)\end{array}$} \\
\hline $\begin{array}{l}\text { Sirsak } \\
(n=32)\end{array}$ & $\begin{array}{l}\text { Non Sirsak } \\
\qquad(n=28)\end{array}$ & $\begin{array}{l}\text { Sirsak } \\
(n=26)\end{array}$ & $\begin{array}{l}\text { Non Sirsak } \\
(n=23)\end{array}$ & $\begin{array}{l}\text { Sirsak } \\
(n=25)\end{array}$ & $\begin{array}{c}\text { Non Sirsak } \\
(n=21)\end{array}$ \\
\hline 32.50 & 32.54 & 40.15 & 40.61 & 41.12 & 42.19 \\
\hline \pm 5.00 & \pm 4.69 & \pm 8.63 & \pm 10.57 & \pm 7.73 & \pm 13.43 \\
\hline
\end{tabular}

Tabel 6. Rerata Subyek Hipertrigliserida Pada Minggu 0, 7, 13 Kelompok Sirsak dan Non Sirsak 


\begin{tabular}{cccccc}
\hline & $\begin{array}{c}\text { Minggu 0 } \\
(\mathbf{n = 3 5})\end{array}$ & \multicolumn{2}{c}{$\begin{array}{c}\text { Minggu 7 } \\
(\mathbf{n = 2 9})\end{array}$} & \multicolumn{2}{c}{ Minggu 13 } \\
$(\mathbf{n}=\mathbf{2 8})$
\end{tabular}

Ilustrasi / gambar

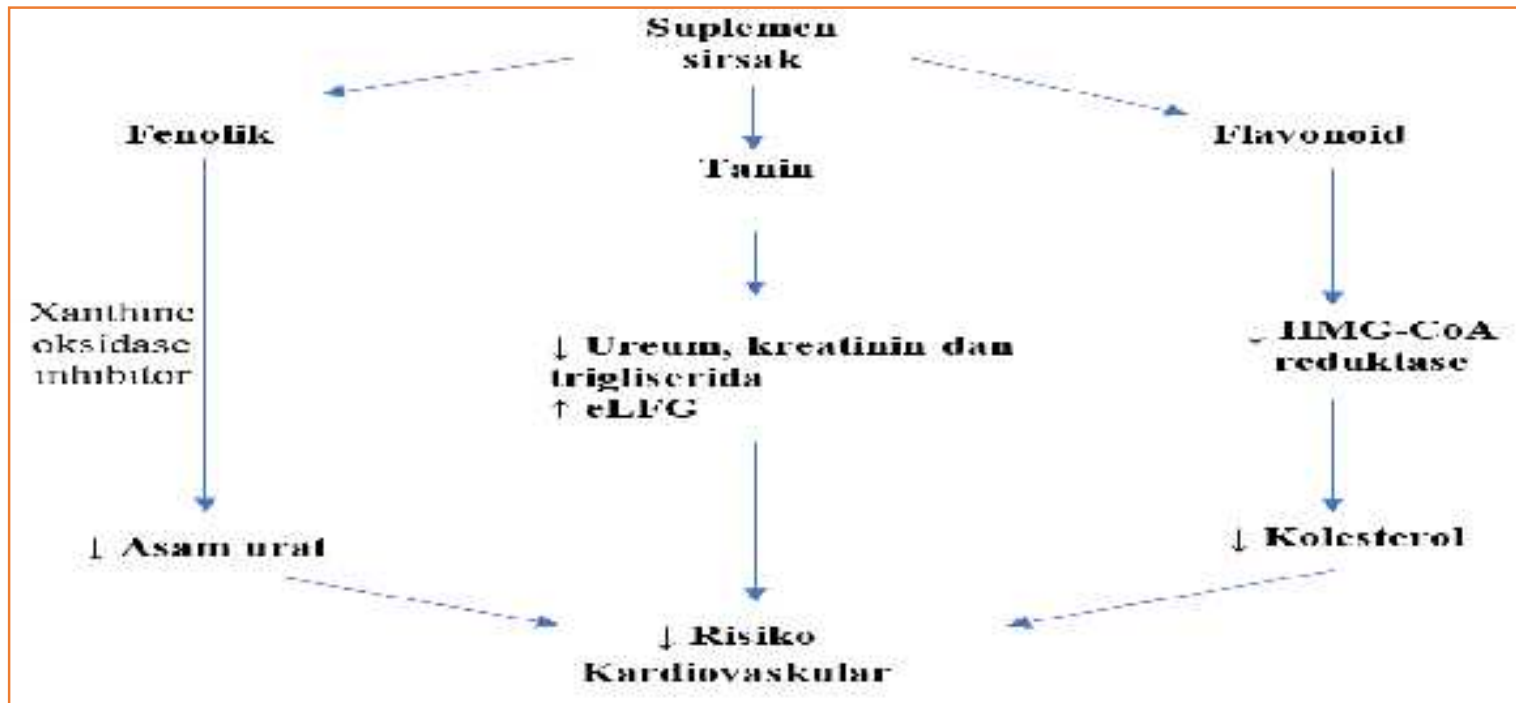

Gambar 1. Pengaruh Buah Sirsak Terhadap Risiko Kardiovaskular (Kolesterol Total, HDL, LDL dan Trigliserida)

\section{Satuan ukuran}

$\begin{array}{ll}\mathrm{mdpl} & =\text { meter di atas permukaan laut } \\ \mathrm{cm} & =\text { centimeter } \\ \mathrm{mg} / \mathrm{dL} & =\text { milligrams/deciliter }\end{array}$

\section{Singkatan dan simbol}

Var

Kol Tot

HDL

LDL

VLDL

Trigli

eLFG

HMG-CoA reduktase
= variabel

$=$ kolesterol total

$=$ high density lipoprotein

= low density lipoprotein

= very low density lipoprotein

$=$ trigliserida

$=$ estimate laju filtrasi glomerulus

=3-hydroxy-3-methyl-glutaryl-coenzyme A reductase 